\title{
The quality of nutrition at an intensive care unit
}

\author{
M.M.P.M. Jansen ${ }^{\mathrm{a}}$, F. Heymer ${ }^{\mathrm{b}}$, J.A. Leusink ${ }^{\mathrm{b}}$, A. de Boer ${ }^{\mathrm{a}, *}$ \\ a'Department of Pharmacoepidemiology \& Pharmacotherapy, Faculty of Pharmacy, Utrecht University, \\ Utrecht, The Netherlands \\ ${ }^{\mathrm{b}}$ Intensive Care Unit, St Antonius Hospital, Nieuwegein, The Netherlands
}

Received 25 March 2001; received in revised form 23 November 2001; accepted 25 November 2001

\begin{abstract}
Adequate nutrition of patients remaining at an intensive care unit (ICU) is of great importance since both over- and undernutrition can lead to serious morbidity and even mortality. The aim of our study was to examine whether patients at an ICU are adequately fed. A prospective follow-up was performed in 39 surgical and medical mechanically ventilated patients who were at least two days on the ICU prior to inclusion. The mean age of the patients was 65 years (range 23 to 88) and $40 \%$ was female. For each patient the following data were collected. First, the exact amounts of macronutrients (carbohydrates, fat and proteins) given over 24 hours by parenteral and/or enteral route were calculated ('administered'). Second, on the same day indirect calorimetric measurement (DeltatrecTM II metabolic monitor) was performed over 18 hours and urinary nitrogen loss was measured over 24 hours in order to estimate energy expenditure and macronutrient usage ('measured'). Third, by means of formulas developed by Harris Benedict and Long we calculated the needs for energy and macronutrients based on the clinical information obtained on the day prior to the day the indirect calorimetric measurements were performed ('calculated'). In 10 patients (26\%) the administered amount of energy was lower than the measured amount. In 16 patients $(41 \%)$ the protein balance was negative. Four of the patients $(10 \%)$ received more than $1500 \mathrm{kcal}$ above the measured amount. In 11 patients $(28 \%)$ the calculated amount of energy was lower than the measured energy expenditure. Coefficients of correlation between measured versus administered, calculated versus administered and measured versus calculated amounts of energy were $0.19(\mathrm{p}=0.25), 0.03(\mathrm{p}=0.87)$ and $0.57(\mathrm{p}=$ 0.0002), respectively. In conclusion, a substantial part of patients at an intensive care unit are not adequately fed. Some improvement of the quality of feeding can be established by using the Harris-Benedict formula in the prescribing of nutrition; measurement of the caloric and protein needs is the preferred method to adequately feed ICU patients. (C) 2002 Elsevier Science Inc. All rights reserved.
\end{abstract}

* Corresponding author. Tel.: +31-30-2536996; fax: +31-30-2539166.

E-mail address: A.deBoer@Pharm.uu.nl (A. de Boer). 
Keywords: Quality of nutrition; Intensive care unit; Harris-Benedict formula; Indirect calorimetric measurement; Energy needs

\section{Introduction}

Adequate nutrition of patients at an intensive care unit (ICU) is important. Both under- and overnutrition with respect to the macronutrients, carbohydrates, fats and proteins can cause several complications. Overnutrition can lead to hyperglycaemia [1,2], elevated blood urea nitrogen concentrations, elevated $\mathrm{CO}_{2}$ production resulting in delayed weaning from mechanical ventilation [1-3], leukopenia, reticulo-endothelial system dysfunction [1], and decreased bacterial clearance [2]. On the other hand underfeeding may cause increased protein turnover, less efficient wound healing, increased risk for decubitus, muscle degradation, decreased resistance to infections [1] and increased mortality in patients with multi-organ failure [2]. Furthermore, inadequate administration of water, electrolytes, trace elements and vitamins can lead to specific problems.

At an ICU especially mechanically ventilated patients need to be artificially fed by parenteral and/or enteral route. Doctors are responsible for the prescription of nutrition to those patients. To provide adequate amounts of nutrition it is important to first assess the patient's nutritional status $[1,2,4-6]$. Second, it is important to estimate the energy expenditure either with help of equations developed by Harris Benedict [1,6,7] and Long et al. [8] or by measurements based on indirect calorimetry [1,2,9-11]. Third, these energy requirements need to be translated to amounts of carbohydrates and fats. Finally, the amount of proteins needs to be estimated. This amount should balance the nitrogen losses, although, this is not always possible in catabolic states. Balance studies have shown that the maximam amount of protein that can be utilized is approximately $1.5 \mathrm{~g} / \mathrm{kg} / 24 \mathrm{~h}$.

Since the introduction of parenteral nutrition the prescribed energy intake in critically ill patients has decreased by up to twofold due to changing insights [12].

In literature there are no studies published in which the quality of feeding in patients at an ICU with respect to both energy and amounts of macronutrients prescribed has been evaluated. Therefore, the aim of this study was to examine whether patients on an ICU, in which indirect calorimetry is not routinely performed, are adequately fed. We compared the prescribed amounts of energy and macronutrients with the needed amounts as measured by indirect calorimetry and with the amounts as estimated by equations of Long et al. Furthermore, determinants of inadequate nutrition were evaluated.

\section{Methods and materials}

\subsection{Study design and patient selection}

We performed a prospective follow-up study to evaluate the quality of nutrition in patients at the surgical and medical ICU of a community hospital in the Netherlands. Patients were 
included when they were on artificial ventilation, in order to make indirect calorimetric measurement easy possible, and if there was no leakage of air through tubes. Furthermore, the amount and composition of the patient's nutrition had to be known (both parenteral and enteral nutrition) and both surgical and medical patients had to be for at least two days at the ICU. Finally, to be able to evaluate the nitrogen balance patients should have at least a diuresis of $500 \mathrm{ml}$. The general aim is that all patients at the ICU, including the patients in this study, should receive optimal nutritional care with adequate amounts of energy and proteins.

\subsection{Nutrition}

\subsubsection{Administered amounts of energy and macronutrients}

The exact composition (amounts of energy and macronutrients) of the nutrition administered to patients either by parenteral and/or enteral route as administered on the day the indirect calorimetry measurement was performed, was obtained from the hospital pharmacy or from product-information.

\subsubsection{Energy expenditure and macronutrient usage}

The indirect calorimetric measurements were conducted with the Deltatrac ${ }^{\mathrm{TM}}$ II metabolic monitor (Datex) by measuring oxygen consumption and carbondioxide production in the tubes of the mechanical ventilator. These measurements were performed on the same day the exact composition of nutrition prescribed to the patient was calculated and took place over 18 hours and were subsequently extrapolated to 24 hours. Energy expenditure was measured by the following formula:

Table 1

Baseline characteristics of the study population

\begin{tabular}{|c|c|c|c|}
\hline Characteristic & $\begin{array}{l}\text { Number } \\
(\mathrm{n}=39)\end{array}$ & $\%$ & Mean \\
\hline Age (years) & - & - & $65.4(\operatorname{rang} 23-88)$ \\
\hline Female gender & 15 & 39 & \\
\hline Height $(\mathrm{cm})$ & - & - & 171 (range $150-190)$ \\
\hline Weight (kg) & - & - & 72 (range 50-100) \\
\hline $\mathrm{BSA}(\mathrm{m} 2)$ & - & - & 1.83 (range $1.50-2.23$ ) \\
\hline Apache-III & - & - & 70 (range $36-101)$ \\
\hline \multicolumn{4}{|l|}{ Reason for admittance } \\
\hline Surgical & 16 & 40 & \\
\hline Medical & 24 & 62 & \\
\hline Emergency & 15 & 38 & \\
\hline \multicolumn{4}{|l|}{ Co-morbidity } \\
\hline COPD/asthma & 10 & 26 & \\
\hline Diabetes mellitus & 3 & 8 & \\
\hline Hypertension & 5 & 13 & \\
\hline Periferal vascular disease & 3 & 8 & \\
\hline Myocardial infarction & 7 & 18 & \\
\hline CVA/TIA & 2 & 5 & \\
\hline
\end{tabular}




$$
\mathrm{EE}=5.5 * \mathrm{VO}_{2}+1.76 * \mathrm{VCO}_{2}-1.99 * \mathrm{U}_{\mathrm{N}}
$$

in which EE signifies energy expenditure, $\mathrm{VO}_{2}$ oxygen consumption $(\mathrm{ml} / \mathrm{min}), \mathrm{VCO}_{2}$ carbondioxide production $(\mathrm{ml} / \mathrm{min})$ and $\mathrm{U}_{\mathrm{N}}$ urinary urea nitrogen excretion $(\mathrm{g} / 24 \mathrm{~h})$. Subsequently the consumption of carbohydrates was calculated by $5.926 * \mathrm{VCO}_{2}-4.189 * \mathrm{VO}_{2}$ $2,539 * \mathrm{U}_{\mathrm{N}}$, the consumption of fats by $2.432 * \mathrm{VO}_{2}-2.432 * \mathrm{VCO}_{2}-1.943 * \mathrm{U}_{\mathrm{N}}$ and protein consumption by $6.250 * \mathrm{U}_{\mathrm{N}}$. The consumption of proteins is underestimated by approximately $20 \%$ when only based on $\mathrm{U}_{\mathrm{N}}$ and not on nitrogen losses by creatinin etc. [7].

\subsubsection{Estimation of energy and macronutrient needs}

To calculate the amount of energy needed by a patient the equations as published by Long were used:

$$
\begin{aligned}
& \mathrm{TDE} \text { men }(\mathrm{kcal} / \text { day })=(66.47+13.75 \mathrm{~W}+5.0 \mathrm{H}-6.76 \mathrm{~A}) * \mathrm{Af} * \mathrm{If} \\
& \mathrm{TDE} \text { women }(\mathrm{kcal} / \text { day })=(655.10+9.56 \mathrm{~W}+1.85 \mathrm{H}-4.68 \mathrm{~A}) * \mathrm{Af} * \mathrm{If}
\end{aligned}
$$

in which TDE, W, H, A, Af and If signify total daily energy needs, weight, height, age, activity factor (dependent on whether a patient is confined to bed or not) and injury factor (correction factor for surgery, infection, trauma or burns), respectively [8]. As all patients were confined to bed for the activity factor in all patients 1.3 was used. For patients whom underwent surgery within 48 hours prior to the indirect calorimetric measurement 1.1 was used for If. When time between surgery and measurement was longer 1.0 was used. For patients having a body temperature between 37 and $38^{\circ} \mathrm{C} 1.0$ was used for the If unless an infection was diagnosed, than 1.1 was used. A temperature between 38 to $39^{\circ} \mathrm{C}$ resulted in an If of 1.3 , between 39 to $40^{\circ} \mathrm{C}$ in 1.5 and above $40^{\circ} \mathrm{C}$ resulted in 1.7 . For any skeletal trauma we used an If of 1.3. No patients needed correction factors for head injury with steroid therapy, blunt trauma or burns. To establish the amounts of carbohydrates and fat

\begin{tabular}{|c|c|c|}
\hline & Nr. of patients & $\%$ \\
\hline Enteral (tube) & 14 & 35.9 \\
\hline Nutrison ${ }^{\circledR}$ & 13 & 33.3 \\
\hline Pulmocare ${ }^{\circledR}$ & 1 & 2.6 \\
\hline Parenteral & 7 & 17.9 \\
\hline $\begin{array}{l}\text { Total parenteral nutrition (all in one mixture } \\
\text { prepared by hospital pharmacy) }\end{array}$ & 2 & 5.1 \\
\hline Glucose, Intralipid ${ }^{\circledR}$ and aminoacids & 4 & 10.3 \\
\hline Glucose and aminoacids & 1 & 2.6 \\
\hline Combination of enteral and parenteral & 18 & 46.2 \\
\hline Nutrison ${ }^{\circledR}$ and aminoacids & 2 & 5.1 \\
\hline Nutrison ${ }^{\circledR}$, glucose and Intralipid ${ }^{\circledR}$ & 5 & 12.8 \\
\hline Prenutrison ${ }^{\circledR}$, glucose, Intralipid ${ }^{\circledR}$ and aminoacids & 8 & 20.5 \\
\hline Prenutrison ${ }^{\circledR}$ and Intralipid ${ }^{\circledR}$ & 1 & 2.6 \\
\hline Pulmocare $^{\circledR}$ and Intralipid ${ }^{\circledR}$ & 1 & 2.6 \\
\hline Reabilan ${ }^{\circledR}$, glucose and Intralipid ${ }^{\circledR}$ & 1 & 2.6 \\
\hline
\end{tabular}

Table 2

Route of administration and composition of nutrition 
needed we used guidelines, published by Sauerwein [12]. These guidelines advise to provide 30 to $50 \%$ of the amount of energy needed as carbohydrates with a maximum of $5 \mathrm{~g} / \mathrm{kg} / 24$ $\mathrm{h}$ and to provide 50 to $70 \%$ in the form of fat. The recommended amount of protein is 1.0 to $1.5 \mathrm{~g} / \mathrm{kg} /$ day protein/amino acids irrespective of the catabolic situation of the patient $[13,14]$. We used the guidelines mentioned above to calculate the borders of the amounts of carbohydrate, fat and proteins per patient.

These calculations were performed on basis of the information of the day prior to the day the indirect calorimetry and the monitoring of the prescribed nutrition was performed because that's in practice the information a physician should use when prescribing a feeding-regimen for the next day.

\subsection{Determinants of inadequate nutrition}

In order to study determinants of inadequate nutrition information was collected on factors that influence energy expenditure. These included age, sex, comorbidity, body surface area (BSA), cerebral condition (normal, somnolent, comatose, sedated), respiratory condition (continuous mechanical ventilation versus pressure support ventilation), infections (airway, urinary tract, sepsis, other, scored by guidelines of the CDC [15], body temperature and use of medication (catecholamines, betablocking agents, sedatives). Furthermore, the nutritional

Table 3

Differences between administered and measured amounts of energy, carbohydrates, fat and protein over 24 hours

\begin{tabular}{|c|c|c|c|c|c|}
\hline \multicolumn{3}{|c|}{ Administered—measured energy (kcal) } & \multicolumn{3}{|c|}{ Administered-measured carbohydrates (g) } \\
\hline & $\begin{array}{l}\mathrm{Nr} \text {. of } \\
\text { patients }\end{array}$ & $\%$ & & $\begin{array}{l}\mathrm{Nr} \text {. of } \\
\text { patients }\end{array}$ & $\%$ \\
\hline$>1500$ & 4 & 10.3 & $>150$ & 8 & 20.5 \\
\hline 1000 to 1500 & 2 & 5.1 & 100 to 150 & 6 & 15.4 \\
\hline 500 to 1000 & 9 & 23.1 & 50 to 100 & 5 & 12.8 \\
\hline 0 to 500 & 14 & 35.9 & 0 to 50 & 6 & 15.4 \\
\hline-500 to 0 & 8 & 20.5 & -50 to 0 & 9 & 23.1 \\
\hline-1000 to -500 & 1 & 2.6 & -100 to -50 & 5 & 12.8 \\
\hline-1500 to -1000 & 1 & 2.6 & -150 to -100 & 0 & 0.0 \\
\hline$<-1500$ & 0 & 0.0 & $<-150$ & 0 & 0.0 \\
\hline \multicolumn{3}{|c|}{ Administered-measured fat $(\mathrm{g})$} & \multicolumn{3}{|c|}{ Administered-measured protein $(\mathrm{g})$} \\
\hline & $\begin{array}{l}\text { Nr. of } \\
\text { patients }\end{array}$ & $\%$ & & $\begin{array}{l}\text { Nr. of } \\
\text { patients }\end{array}$ & $\%$ \\
\hline$>150$ & 2 & 5.1 & $>150$ & 3 & 7.7 \\
\hline 100 to 150 & 3 & 7.7 & 100 to 150 & 2 & 5.1 \\
\hline 50 to 100 & 12 & 30.8 & 50 to 100 & 2 & 5.1 \\
\hline 0 to 50 & 8 & 20.5 & 0 to 50 & 16 & 41.0 \\
\hline-50 to 0 & 7 & 17.9 & -50 to 0 & 13 & 33.3 \\
\hline-100 to -50 & 2 & 5.1 & -100 to -50 & 3 & 7.7 \\
\hline-150 to -100 & 4 & 10.3 & -150 to -100 & 0 & 0.0 \\
\hline$<-150$ & 1 & 2.6 & $<-150$ & 0 & 0.0 \\
\hline
\end{tabular}


route was recorded (enteral and/or parenteral). All factors, except for age, sex and comorbidity were collected on the day the indirect calorimetry was performed.

\subsection{Statistical analysis}

For each patient we calculated the differences in the administered, measured and calculated amounts of energy, carbohydrates, fats and proteins. Next to the intentional prescribed nutrition some patients also received energy and macronutrients by other means. For instance propofol (often used to sedate patients on artificial ventilation) is dissolved in a fat-emulsion and albumin and haemaccel infusions contain proteins. Therefore, when appropriate we calculated the above mentioned differences with and without including these 'hidden' macronutrient sources. The Pearson correlations between the administered, measured and calculated amounts of energy were calculated. Finally, the association between determinants and a negative energy balance was estimated by logistic regression. All analysis were performed with SPSS v6.1. A p-value below 0.05 was considered as statistically significant.

\section{Results}

\subsection{Patients}

Of 40 patients satisfying the inclusion criteria 1 patient was excluded because of a short bowel syndrome since this condition probably had compromised the absorption of the enteral

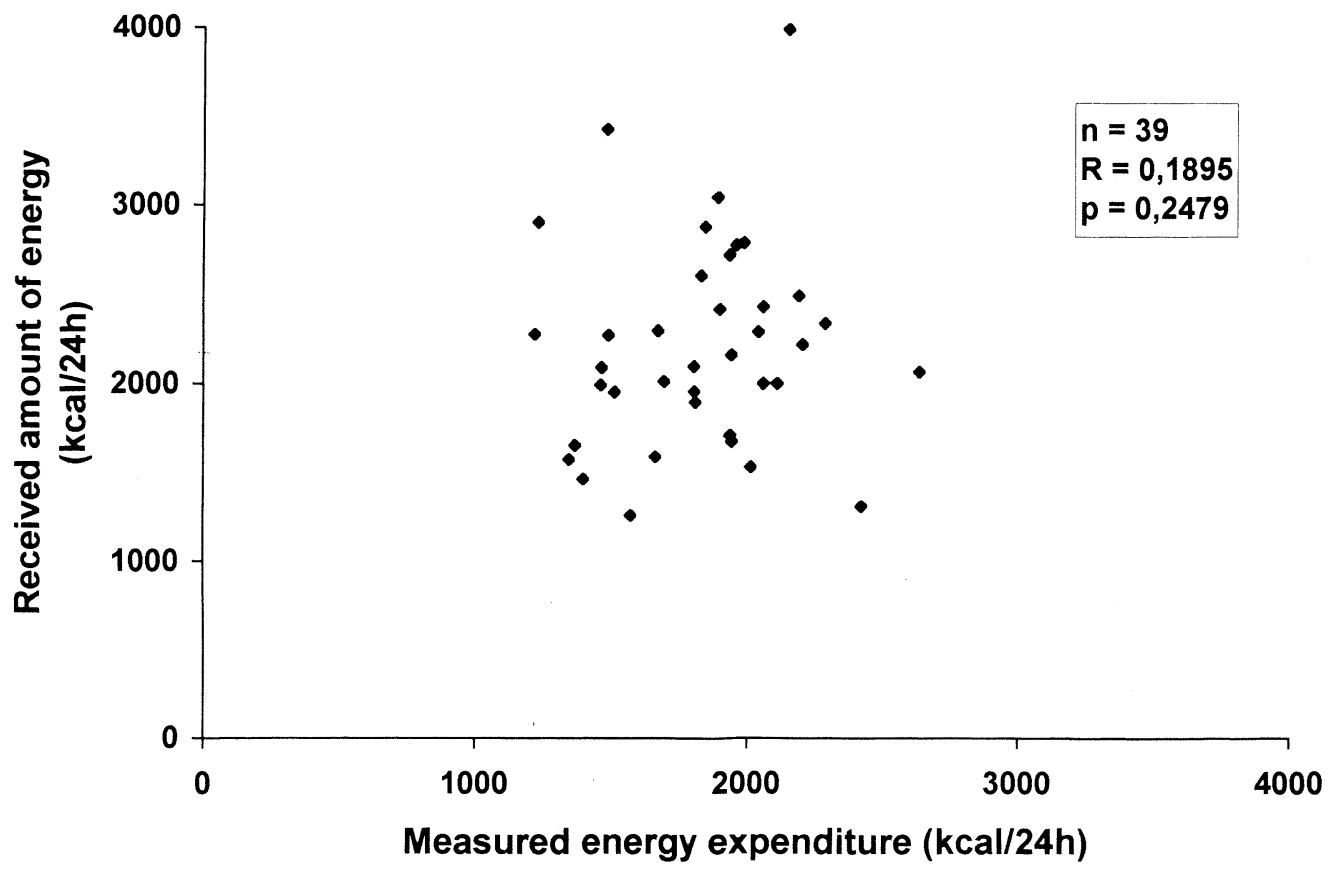

Fig. 1. Correlation between administered and measured amount of energy. 
Table 4

Differences between calculated and measured amounts of energy, carbohydrates, fat and protein over 24 hours

\begin{tabular}{|c|c|c|c|c|c|}
\hline \multicolumn{3}{|c|}{ Calculated-measured energy (kcal) } & \multicolumn{3}{|c|}{ Calculated-measured carbohydrates* } \\
\hline & $\begin{array}{l}\mathrm{Nr} \text {. of } \\
\text { patients }\end{array}$ & $\%$ & & $\begin{array}{l}\text { Nr. of } \\
\text { patients }\end{array}$ & $\%$ \\
\hline$>1500$ & 0 & 0.0 & & & \\
\hline 1000 to 1500 & 1 & 2.6 & $<30 \%$ & 20 & 51.3 \\
\hline 500 to 1000 & 5 & 12.8 & $30-50 \%$ & 15 & 38.5 \\
\hline 0 to 500 & 22 & 56.4 & $>50 \%$ & 4 & 10.3 \\
\hline-500 to 0 & 10 & 25.6 & & & \\
\hline-1000 to -500 & 1 & 2.6 & & & \\
\hline-1500 to -1000 & 0 & 0.0 & & & \\
\hline$<-1500$ & 0 & 0.0 & & & \\
\hline \multicolumn{3}{|c|}{ Calculated-measured fat* } & \multicolumn{3}{|c|}{ Calculated-measured protein } \\
\hline & $\begin{array}{l}\mathrm{Nr} \text {. of } \\
\text { patients }\end{array}$ & $\%$ & & $\begin{array}{l}\text { Nr. of } \\
\text { patients }\end{array}$ & $\%$ \\
\hline$>50 \%$ & 22 & 56.4 & $<1.0 \mathrm{~g} / \mathrm{kg} / 24 \mathrm{~h}$ & 24 & 61.5 \\
\hline $50-70 \%$ & 9 & 23.1 & $1.0-1.5 \mathrm{~g} / \mathrm{kg} / 24 \mathrm{~h}$ & 7 & 18.0 \\
\hline$>70 \%$ & 8 & 20.5 & $<1.5 \mathrm{~g} / \mathrm{kg} / 24 \mathrm{~h}$ & 8 & 20.5 \\
\hline
\end{tabular}

* Per patients the amounts of carbohydrates and fats were calculated based on the percentage recommendation and expressed in $\mathrm{g} / 24 \mathrm{~h}$.

nutrition that was administered to the patient. Baseline characteristics of the study group are presented in Table 1. The composition of the nutrition and the route of administration in all patients are presented in Table 2 . Most patients (46\%) received a combination of enteral and parenteral nutrition.

\subsubsection{Administered versus measured energy and macronutrients}

In 10 of the 39 patients $(26 \%)$ the administered amount of energy was lower than the amount needed as measured by indirect calorimetry (Table 3). In 8 of these 10 patients the shortage was between 0 to $500 \mathrm{kcal}$ and in the other 2 between 500 and $1500 \mathrm{kcal}$. The correlation between the administered and measured amount of energy was low and nonsignificant $(\mathrm{r}=0.19 ; \mathrm{p}=0.25$; Fig. 1$)$. The lack of energy was approximately equally divided over the carbohydrates (36\% of the patients received not insufficient amounts) and fats (also 36\% of the patients) (Table 3). 29 patients received more energy than needed and 4 of them (10\%) even received more than $1500 \mathrm{kcal}$. When the energy supplied by propofol infusions was excluded from the analysis the number of patients with more or less energy administration than their energy expenditure were 22 and 17, respectively (data not shown). After ignorance of the propofol, albumin and Haemaccel infusions the number of patients receiving an excess of fats and proteins dropped to 19 and 17, respectively (data not shown). In 16 patients $(41 \%)$ the nitrogen balance was negative, however, as the measured amount of protein utilization is underestimated by approximately $20 \%$, this number is also an underestimate. 


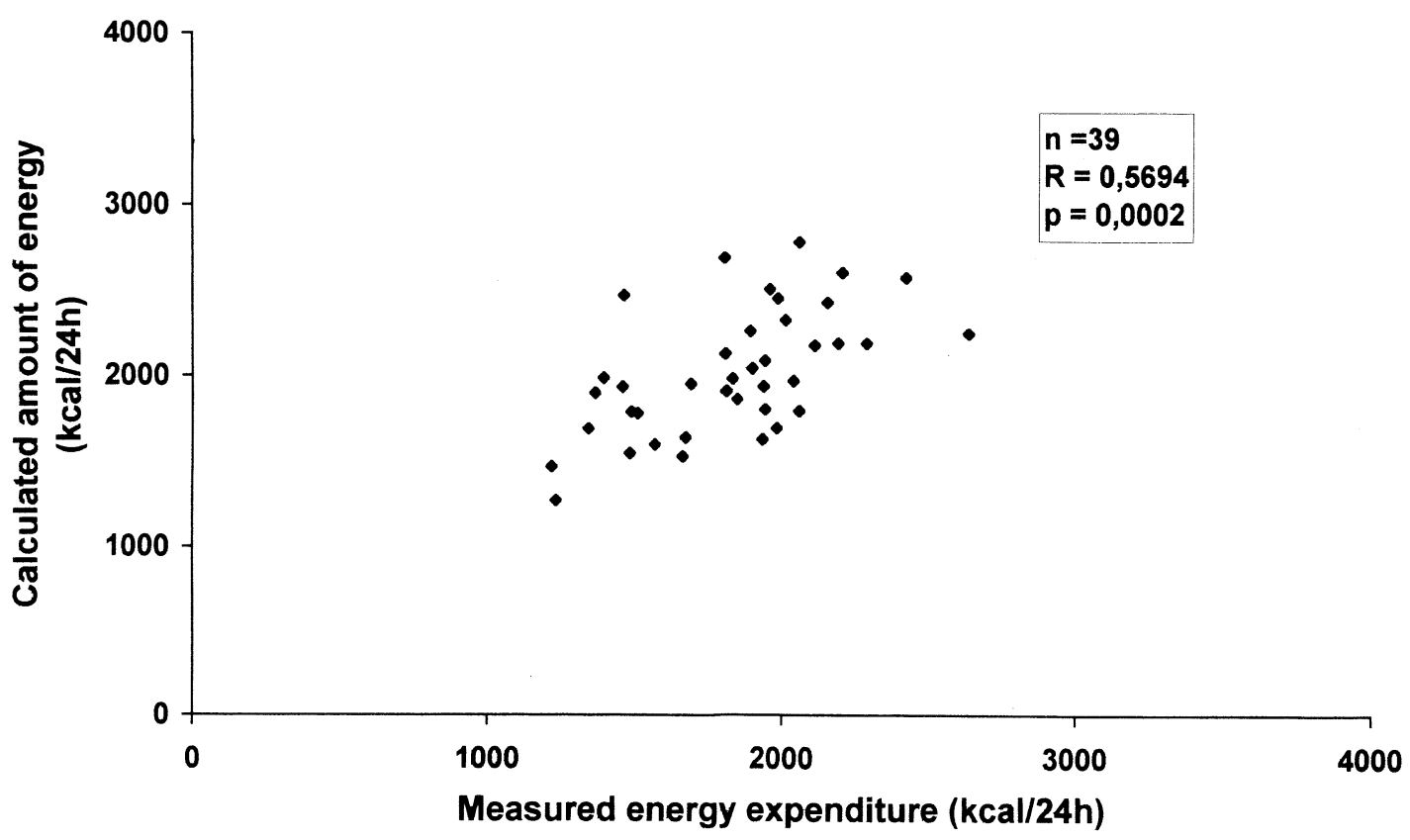

Fig. 2. Correlation between calculated and measured amount of energy.

\subsubsection{Calculated versus measured energy and macronutrients}

In 11 patients $(28 \%)$ the calculated amount of energy was lower than the measured energy expenditure with 10 patients within the range of -500 to zero kcal (Table 4). In 6 patients $(15 \%)$ the calculated amount was above $500 \mathrm{kcal}$. The correlation between the calculated and measured amount of energy was 0.57 ( $\mathrm{p}=0.0002$ ) (Fig. 2). Compared to fats and proteins, the calculated amounts of carbohydrates corresponded best with the measured amounts (in 15 patients the amount of carbohydrates measured was within the calculated borders of the amount of carbohydrates) (Table 4). When the prescribed amounts of carbohydrates and fats would have been based on the calculated amounts, the percentage of patients who would receive too little of these macronutrients would have been 10 and $21 \%$, respectively. When the administration of proteins would have been based on the generally accepted recommendations (maximum amount $1.5 \mathrm{~g} / \mathrm{kg} / 24 \mathrm{~h}$ ) at least $21 \%$ of the patients would have had a negative protein balance.

\subsubsection{Administered versus calculated energy and macronutrients}

Compared to the calculated amounts of energy per individual, 16 patients $(41 \%)$ received less than this amount and 23 patients $(59 \%)$ received more with 5 patients receiving even more than $1500 \mathrm{kcal}$ (Table 5). There was virtually no correlation between the calculated and administered amount of energy $(r=0.028 ; p=0.87)$ (Fig. 3). For 19 (49\%) and 9 (23\%) patients the administered amount of proteins was below and above the recommended amount (between 1.0 to $1.5 \mathrm{~g} / \mathrm{kg} / 24 \mathrm{~h}$ ), respectively. For the carbohydrates and fats $33 \%$ and $44 \%$ of the patients received less of these macronutrients than the lower border of the recommended amounts as based on the equations of Long et al. 
Table 5

Differences between administered and calculated amounts of energy, carbohydrates, fat and protein over 24 hours

\begin{tabular}{|c|c|c|c|c|c|}
\hline \multicolumn{3}{|c|}{ Administered-calculated energy (kcal) } & \multicolumn{3}{|c|}{ Administered-calculated carbohydrates* } \\
\hline & $\begin{array}{l}\text { Nr. of } \\
\text { patients }\end{array}$ & $\%$ & & $\begin{array}{l}\text { Nr. of } \\
\text { patients }\end{array}$ & $\%$ \\
\hline$>1500$ & 4 & 10.3 & & & \\
\hline 1000 to 1500 & 2 & 5.1 & $<30 \%$ & 13 & 33.3 \\
\hline 500 to 1000 & 4 & 10.3 & $30-50 \%$ & 18 & 46.2 \\
\hline 0 to 500 & 13 & 33.3 & $>50 \%$ & 8 & 20.5 \\
\hline-500 to 0 & 11 & 28.2 & & & \\
\hline-1000 to -500 & 4 & 10.3 & & & \\
\hline-1500 to -1000 & 1 & 2.6 & & & \\
\hline$<-1500$ & & & & & \\
\hline \multicolumn{3}{|c|}{ Administered-calculated fat* } & \multicolumn{3}{|c|}{ Administered-calculated protein } \\
\hline & $\begin{array}{l}\text { Nr. of } \\
\text { patients }\end{array}$ & $\%$ & & $\begin{array}{l}\mathrm{Nr} \text {. of } \\
\text { patients }\end{array}$ & $\%$ \\
\hline$<50 \%$ & 17 & 43.6 & $<1.0 \mathrm{~g} / \mathrm{kg} / 24 \mathrm{~h}$ & 19 & 48.7 \\
\hline $50-70 \%$ & 11 & 28.8 & $\begin{array}{l}1.0-1.5 \mathrm{~g} / \mathrm{kg} / \\
24 \mathrm{~h}\end{array}$ & 11 & 28.1 \\
\hline$>70 \%$ & 11 & 28.8 & $>1.5 \mathrm{~g} / \mathrm{kg} / 24 \mathrm{~h}$ & 9 & 23.1 \\
\hline
\end{tabular}

* Per patient the amounts of carbohydrates and fats were calculated based on the percentage recommendations and expressed in $\mathrm{g} / 24 \mathrm{~h}$.

\subsubsection{Determinants of a negative energy balance}

Of the well-known factors that are related to energy expenditure it appeared that patients with an infection had a 14 times higher chance $(\mathrm{p}=0.04)$ on a negative energy balance than patients without an infection (Table 6).

\section{Discussion}

This study demonstrated that a substantial part of the patients artificially fed at the ICU are under- or overfed. Ten patients (25\%) did not receive enough energy and 19 patients (49\%) received insufficient amounts of proteins (less than $1.0 \mathrm{~g} / \mathrm{kg} / 24 \mathrm{~h}$ ). On the other hand 6 patients $(15 \%)$ received more than $1000 \mathrm{kcal}$ too much per 24 hour and 9 patients $(23 \%)$ received more than $1.5 \mathrm{~g} / \mathrm{kg} / 24 \mathrm{~h}$ which is more than the optimal amount of proteins.

Although the administered amounts of energy showed a substantial variation (range 1464 to $4148 \mathrm{kcal} / 24 \mathrm{~h}$ ), these amounts appeared not to be based on the equations of Long et al. Especially patients with an infection had an increased chance to be underfed. As the calculated amounts of energy and macronutrients per patient as based on the equations of Long et al. showed a good correlation with the needed amounts, the use of those formulas would have improved the quality of feeding. However, still $28 \%$ of the patients would have received insufficient amounts of energy when based on these algorhythms. Therefore, other 


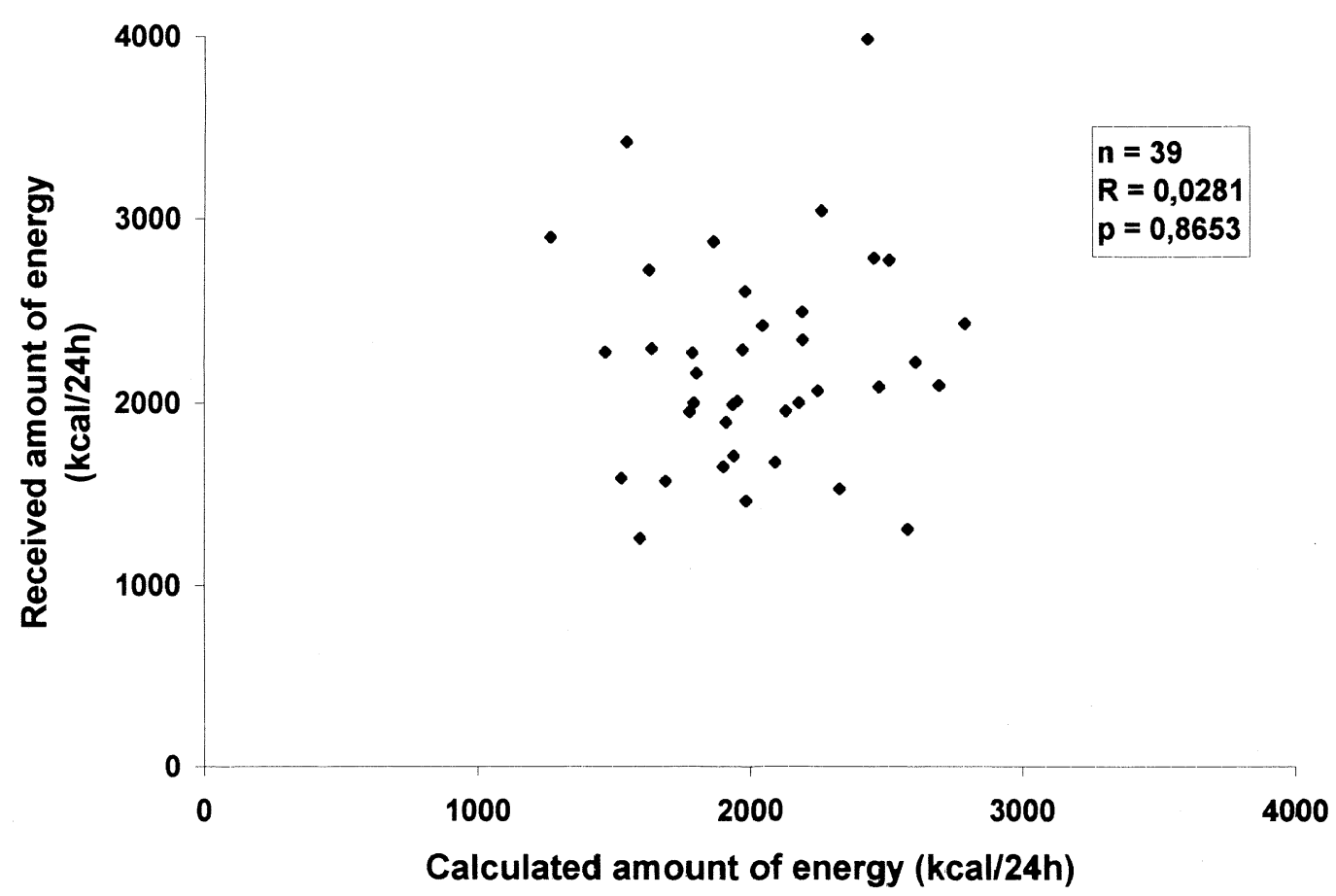

Fig. 3. Correlation between administered and calculated amount of energy.

ways to estimate the energy requirements per patient are needed. In this respect the development of bed side measurement of energy needs by indirect calorimetry is important. In our study in which we measured energy expenditure over 18 hours we could demonstrate that measurements of 15 minutes already provided reliable estimates of energy expenditure over 24 hours (data not shown). When the reliability of short term measurements is further confirmed the use of indirect calorimetry to support the prescribing of nutrition becomes feasible.

The over- and underprescribing of proteins is remarkable since the amount of proteins that should be administered only partly depends on the condition of the patient and should always be between 1.0 to $1.5 \mathrm{~g} . / \mathrm{kg} / 24 \mathrm{~h}$. On inquiry the reason appeared to be the standard amounts of proteins in available preparations (e.g. $6 \%$ aminoacids $=30 \mathrm{~g} / 500 \mathrm{ml}$ ). The amounts of protein and fluid volume per bottle did not correspond very well with the requirements.

Although several patients metabolized more proteins than $1.5 \mathrm{~g} / \mathrm{kg} / 24 \mathrm{~h}$ it is not necessary to try to balance these nitrogen losses since above 1.5 the maximum capacity to utilize proteins is superseded.

We have not studied whether the under and overfeeding had any clinical implications. Furthermore, there are no data at which level of over- or undernutrition adverse effects will occur. Although the direct clinical implications of our findings is not clear it is obvious that over and underfeeding will increase the patients' risk on adverse outcome and therefore needs to be precluded.

In conclusion our study demonstrated that a substantial part of patients at an ICU were 
Table 6

Associations between determinants and administration of insufficient amount of energy

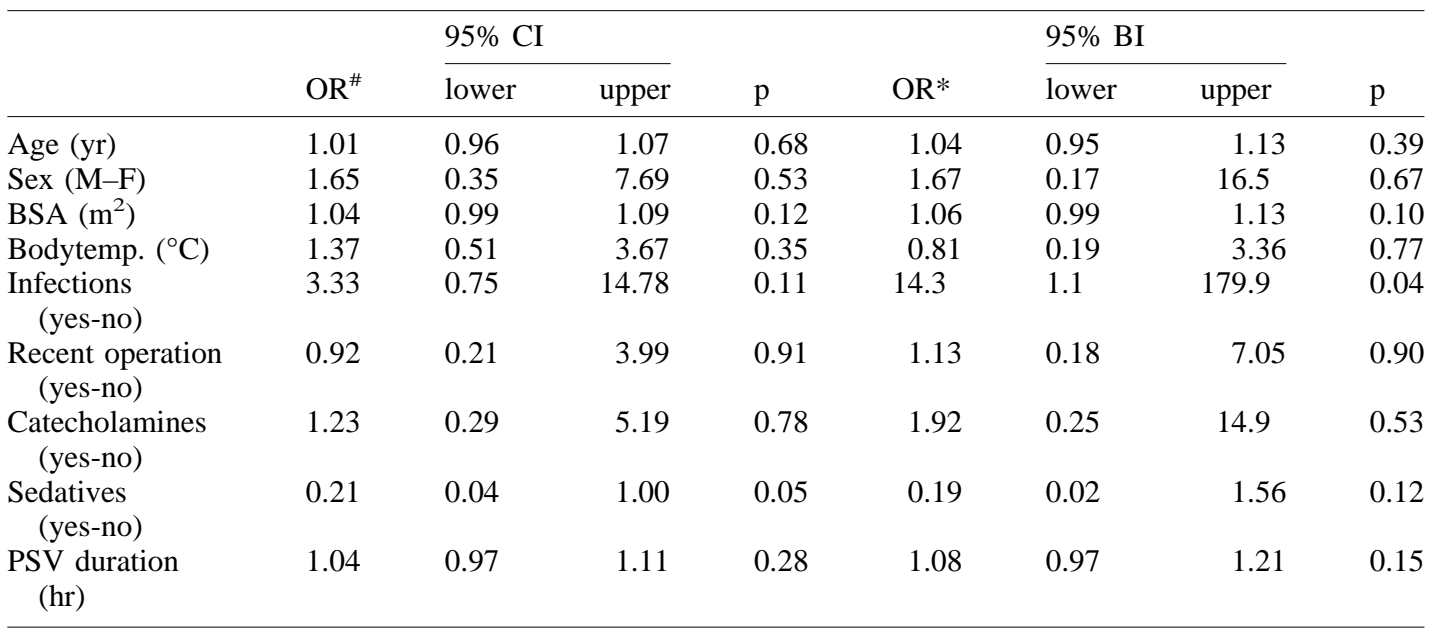

\# Unadjusted; * Adjusted for all other variables in the table.

PSV $=$ Pressure support ventilation.

underfed. Although the use of the equations of Long et al. could have improved the quality of feeding in those patients a substantial part would still have been underfed. The application of routine bed side short term measurement of energy requirements by indirect calorimetry is an important development in this respect.

\section{Acknowledgments}

Contributors: MMPMJ was responsible for data collection, interpretation, analyses and writing the paper. FH participated in the protocol design, interpretation of the data end editing the paper. JAL initiated the research project, participated in the design of the study protocol, interpretation of the data and editing the paper. AdB participated in the protocol design, interpretation, statistical analyses and editing the paper. Financial support came only from the departments in which the investigators worked during the investigations. There is no conflict of interest.

\section{References}

[1] Lanschot JJB. Metabolic gas exchange in critically ill surgical patients. 1st ed. Gravenhage: Drukkerij J.H. Pasmans B.V., 1987.

[2] McClave SA. Effective utilisation of indirect calorimetry during critical care. Intensive Care World 1992;9:194-200.

[3] Sykes K. Respiratory support. 2nd ed. BMJ Publishing Group, 1995.

[4] Elia M. Changing concepts of nutrient requirements in disease: implications for artificial nutritional support. Lancet 1995;345:1279-84. 
[5] Ravussin E, Lillioja S, Anderson TE, Cristin L, Bogardus C. Determinants of 24-hour energy expenditure in man. J Clin Invest 1986;78:1568-78.

[6] Payne JJ, Grimble G, Silk D. Artificial nutrition support in clinical practice. 2nd ed. Edward Arnold (division of Hodder Headline PLC), 1995.

[7] Phillips GD, Odgers CL. Parenteral and enteral nutrition: a practical guide. 3rd ed. Edinburg: Churchill Livingstone, 1986.

[8] Zaloga GP. Nutrition in clinical care. 3rd ed. St. Louis: Mosby, 1994.

[9] Cunningham KF, Aeberhardt LE, Wiggs R, Phang PT. Appropriate interpretation of indirect calorimetry for determining energy expenditure of patients in intensive care units. Am J Surg 1994;167:547-9.

[10] Ferraninni E. The theoretical bases of indirect calorimetry: a review. Metabolism 1988;37:287-301.

[11] Simonson DC, DeFronzo RA. Indirect calorimetry: methodological and interpretative problems. Am J Physiol 1990;258:E399-412.

[12] Sauerwein HP. Parenterale voeding. 1st ed. Utrecht: Wetenschappelijke Uitgeverij Bunge, 1989.

[13] Metthews ED, Fong Y. Amino acids and protein metabolism. In: Rombeau JL, Caldwell MD, editors. Clinical nutrition: parenteral nutrition. Philadelphia: WB Saunders Company, 1993. p. 75-112.

[14] Crim MC, Munro HN. Proteins and aminoacids. In: Shils ME, Olson JA, Shike M, editors. Modern nutrition in health and disease (8th ed). USA: Williams \& Williams, 1994. p. 3-35.

[15] Garner JS, Jarvis WR, Emori TG, Horan TC, Hughes JM. CDC definitions for nosocomial infections. Am Rev Respir Dis 1989;139:877-84. 